\title{
Реформирование внутреннего
} государственного финансового контроля:
цели, задачи и правовые вызовы ${ }^{1}$

Аннотация. Рассмотрены цели, задачи и направления реформирования внутреннего государственного финансового контроля в целях его совершенствования и повышения эффективности контрольных мероприятий. В статье определены причины, подтолкнувшие законодательную и исполнительную власть к преобразованиям государственного финансового контроля, имеющим системный характер. Значительное место уделено функциональным формам государственного финансового контроля - внутреннему финансовому контролю и внутреннему финансовому аудиту, осуществляемым администраторами бюджетных средств, не являющимися органами внутреннего государственного финансового контроля. На основе анализа нормативных правовых и иных актов, методических рекомендаций выявляются сущность внутреннего финансового контроля и внутреннего финансового аудита, их соотношение между собой и с внутренним государственным финансовым контролем, предлагаются меры по повышению качества работы контрольных органов. Представлена система и уровни правового регулирования всех направлений финансового контроля, реализуемого органами исполнительной власти, предложены способы обеспечения независимости органов, реализующих функциональные формы финансового контроля.

Ключевые слова: финансовый контроль; государственный финансовый контроль; внутренний финансовый контроль; внутренний финансовый аудит; объекты контроля; методы контроля; органы контроля; финансовое право; бюджет; контрольные органы.

Для цитирования: Ялбулганов А. А. Реформирование внутреннего государственного финансового контроля: цели, задачи и правовые вызовы // Актуальные проблемы российского права. - 2020. - Т. 15. - № 11. C. 076-094. - DOI: 10.17803/1994-1471.2020.120.11.076-094.

1 Статья подготовлена в ходе проведения исследования (проект № 19-01-030) в рамках программы «Научный фонд Национального исследовательского университета “Высшая школа экономики” (НИУ ВШЭ)» в 2019-2020 гг. и в рамках государственной поддержки ведущих университетов Российской Федерации «5-100».

(C) Ялбулганов А. А., 2020

* Ялбулганов Александр Алибиевич, доктор юридических наук, профессор, главный научный сотрудник, Российский университет дружбы народов (РУДН) ул. Миклухо-Маклая, д. 6, г. Москва, Россия, 117198 yalbulganov@mail.ru 


\title{
The Internal State Financial Control Reform: Tasks, Objectives and Legal Challenges ${ }^{2}$
}

\author{
Aleksandr A. Yalbulganov, Dr. Sci. (Law), Full Professor, Chief Research Fellow, RUDN University \\ ul. Miklukho-Maklaya, d. 6, Moscow, Russia, 117198 \\ yalbulganov@mail.ru
}

\begin{abstract}
The paper examines the objectives, tasks and directions for the internal state financial control in order to improve efficiency of control and supervisory measures. It identifies the reasons that encouraged the legislative and executive powers to transform the state financial control, which have a systemic nature. A significant place is devoted to the functional forms of state financial control-internal financial control and internal financial audit carried out by budget funds administrators other than internal state financial control bodies. Based on the analysis of normative legal and other acts and methodical recommendations the author elucidates the essence of internal financial control and internal financial audit, the balance between them and the internal state financial control and proposes measures to improve the efficiency of the controlling bodies. The paper represents the system and levels of legal regulation of all directions of financial control implemented by executive authorities, suggests methods of ensuring independence of bodies implementing functional forms of financial control.

Keywords: financial control; state financial control; internal financial control; internal financial audit; objects of control; methods of control; bodies of control; financial law; budget, controlling bodies.

Cite as: Yalbulganov AA. Reformirovanie vnutrennego gosudarstvennogo finansovogo kontrolya: tseli, zadachi i pravovye vyzovy [The Internal State Financial Control Reform: Tasks, Objectives and Legal Challenges]. Aktualnye problemy rossiyskogo prava. 2020;15(11):76-94. DOI: 10.17803/1994-1471.2020.120.11.076-094. (In Russ., abstract in Eng.).
\end{abstract}

\section{Введение}

Основной целью реформирования внутреннего государственного финансового контроля (далее - ГФК) является повышение эффективности контрольных мероприятий. Главные направления финансово-контрольных преобразований нашли отражение в Бюджетном кодексе РФ, в актах Президента РФ и Правительства РФ. Задачи сформулированы четко и конкретно - проведение регулярных, качественных, с использованием высоких цифровых технологий контрольных мероприятий, направленных на «защиту» и целевое использование бюджетных средств, средств государственных внебюджетных фондов, их доведение до конечного получателя, использование исключительно на достижение результата в финансировании запланированных государством мероприятий. Все задачи должны ставиться в зависимости от главной, глобальной цели и формулироваться просто и понятно. Мы видим, что в большинстве случаев они находят отражение в нормативных правовых актах Минфина России и правовых актах Федерального казначейства.

Концептуальные изменения нормативной правовой базы ГФК, организационные преобразования в системе органов, осуществляющих ГФК, содержательные изменения в подходах, способах и приемах осуществления ГФК, имевшие системный характер, позволяют по совокупности реализуемых мероприятий говорить о ресрорме внутреннего государственного финансового контроля.

Во-первых, согласно изменениям, внесенным в гл. 26 Бюджетного кодекса РФ от 31.07.1998

2 The reported study was prepared in the course of the research (project № 19-01-030) according to the HSE Academic Fund Programme in 2019-2020 and according to 5-100 Project providing government support for leading universities of the Russian Federation. 
№ 145-Ф3 ${ }^{3}$, расширились цели и вектор ГФК теперь это обеспечение соблюдения положений правовых актов, регулирующих бюджетные отношения, правовых актов, обусловливающих публичные нормативные обязательства и обязательства по иным выплатам физическим лицам из бюджетов бюджетной системы Российской Федерации, а также соблюдения условий государственных (муниципальных) контрактов, договоров (соглашений) о предоставлении средств из бюджета.

Во-вторых, изменилась система органов, осуществляющих внутренний ГФК. Указом Президента РФ от 02.02.2016 № 41 «О некоторых вопросах государственного контроля и надзора в финансово-бюджетной сфере» ${ }^{4}$ в целях совершенствования государственного контроля и надзора в финансово-бюджетной сфере, оптимизации структуры федеральных органов исполнительной власти была упразднена Федеральная служба финансово-бюджетного надзора. Ее функции по контролю и надзору в финансово-бюджетной сфере, по внешнему контролю качества работы аудиторских организаций, опре- деленных Федеральным законом от 30.12.2008 № 307-Ф3 «Об аудиторской деятельности», были переданы Федеральному казначейству. В итоге функции и полномочия Федерального казначейства значительно расширились, а с учетом и иных полномочий, предоставленных этому органу Правительством РФ и Минфином России, эта служба превратилась в «суперведомство» по организации и осуществлению внутреннего государственного финансового контроля.

В-третьих, это функциональные изменения Внутреннего ГФК, осуществляемого Федеральным казначейством и контрольными органами субъектов Российской Федерации с использованием новых подходов, способов, приемов, а также, на наш взгляд, создание ответвления от внутреннего ГФК для широкого охвата подконтрольных объектов. В данном случае идет речь о функциональных формах внутреннего ГФК - о внутреннем финансовом контроле и внутреннем финансовом аудите, осуществляемых администраторами бюджетных средств ${ }^{5}$, не являющимися органами ГФК.

3 Концептуальные изменения 2013 г. коснулись как внешнего, так и внутреннего государственного (муниципального) финансового контроля. Новая редакция гл. 26 «Основы государственного (муниципального) финансового контроля» БК РФ установила на тот момент новый концептуальный подход к организации бюджетного контроля. Преобразования коснулись организационно-правовых основ осуществления государственного (муниципального) финансового контроля, вопросов наделения финансовых органов субъектов Российской Федерации полномочиями по внутреннему государственному финансовому контролю в бюджетной сфере и др. Исследуемая тема не теряет своей актуальности, о чем свидетельствуют многочисленные научные публикации: монографии и иные научные издания (например: Голубев А. В. Правовой статус субъектов финансово-бюджетного контроля. М. : Норма, 2011. 176 с. ; Государственный финансовый контроль: современное правовое регулирование / под общ. ред. А. А. Ялбулганова. Вып. 11. М., 2014. 176 с. ; Контроль в финансово-бюджетной сфере : научно-практическое пособие / И. И. Кучеров, Н. А. Поветкина, Н. Е. Абрамова [и др.] ; отв. ред. И. И. Кучеров, Н. А. Поветкина. М. : ИЗиСП, Контракт, 2016. 320 с. ; Право и финансовый контроль : монография / отв. ред. Е. И. Иванова, Н. М. Казанцев. М. : Эксмо, 2009. 332 с. ; Правовое регулирование финансового контроля в Российской Федерации: проблемы и перспективы : монография / отв. ред. Е. Ю. Грачева. М. : Норма, Инфра-М, 2013. 384 с.), научные статьи (например: Артюхин Р. Е. Составление, внешняя проверка, рассмотрение и утверждение бюджетной отчетности: научно-практический комментарий раздела VIII.1 Бюджетного кодекса Российской Федерации // Реформы и право. 2013. № 1. С. 25-34 ; Козырин А. Н. Правовые основы государственного и муниципального финансового контроля в Российской Федерации // Реформы и право. 2014 . № 1. С. 67-75; Прокофьев С. Е. Новации в сфере государственного финансового контроля, осуществляемого Казначейством России // Финансы и кредит. 2015. № 10 (634). С. 2-11).

4 С3 РФ. 2016. № 6. Ст. 831.

5 К администраторам бюджетных средств относятся главные распорядители (распорядители) бюджетных средств, главные администраторы (администраторы) доходов бюджета, главные администраторы (администраторы) источников финансирования дефицита бюджета, получатели бюджетных средств. 
Возникает вопрос, каково место функциональных форм контроля в системе внутреннего ГФК, проводимого органами исполнительной власти, наделенными бюджетными полномочиями? Внутренний финансовый контроль (далее - ВФК) фактически (с некоторыми оговорками) осуществляется внутренними структурными подразделениями администратора бюджетных средств, а внутренний финансовый аудит (далее - ВФА) может рассматриваться как «контроль над контролерами».

Наконец, важное место начинает занимать активно внедряемый бюджетный мониторинг. В действующей редакции БК РФ, впрочем, как и в недействующих редакциях БК РФ бюджетный мониторинг никак не был обозначен. По своей сущности, учитывая содержание правовых актов, предусматривающих мониторинг, он близок к методам осуществления внутреннего ГФК. В Федеральном законе от 05.04.2013 № 41-Ф3 "О Счетной палате Российской Федерации» мониторинг отнесен к методам осуществления контрольной и экспертно-аналитической деятельности и применяется в целях сбора и анализа информации о предмете и деятельности объекта аудита (контроля) на системной и регулярной основе. По своему содержанию данное понятие мониторинга близко к содержанию понятия обследования, закрепленного в БК РФ, так же как метода ГФК. В обоих случаях они применяются для анализа и оценки деятельности объектов контроля.

\section{1. Правовое регулирование внутреннего ГФК}

Система правового регулирования внутреннего ГФК на 31.05.2020

\begin{tabular}{|c|c|}
\hline ГФК & Наименование НПА \\
\hline Законодательный уровень регулирования & Глава 26 БК РФ \\
\hline Подзаконный уровень регулирования & $\begin{array}{l}\text { 1. Постановление Правительства РФ от } 28.11 .2013 \\
\text { № } 1092 \text { «О порядке осуществления Федеральным } \\
\text { казначейством полномочий по контролю в финансово- } \\
\text { бюджетной сфере» (далее - Постановление № 1092). } \\
\text { 2. Постановление Правительства РФ от 06.02.2020 } \\
\text { № } 100 \text { «Об утверждении федерального стандарта } \\
\text { внутреннего государственного (муниципального) } \\
\text { финансового контроля “Права и обязанности } \\
\text { должностных лиц органов внутреннего } \\
\text { государственного (муниципального) финансового } \\
\text { контроля и объектов внутреннего государственного } \\
\text { (муниципального) финансового контроля (их } \\
\text { должностных лиц) при осуществлении внутреннего } \\
\text { государственного (муниципального) финансового } \\
\text { контроля”» (вступает в силу с 01.07.2020) (далее - } \\
\text { Федеральный стандарт № 100). } \\
\text { 3. Постановление Правительства РФ от 06.02.2020 } \\
\text { № 95 «Об утверждении федерального стандарта } \\
\text { внутреннего государственного (муниципального) } \\
\text { финансового контроля “Принципы контрольной } \\
\text { деятельности органов внутреннего государственного } \\
\text { (муниципального) финансового контроля” (вступает } \\
\text { в силу с 01.07.2020) (далее - Федеральный стандарт } \\
\text { № 95) }\end{array}$ \\
\hline $\begin{array}{l}\text { Подзаконный уровень: акты Федерального } \\
\text { казначейства } \\
\text { Законодательный/подзаконный уровень } \\
\text { субъекта РФ }\end{array}$ & $\begin{array}{l}\text { Приказы Федерального казначейства, контрольных } \\
\text { органов субъектов РФ, утверждающие формы, порядок } \\
\text { проведения, планирование контрольных мероприятий, } \\
\text { размещение информации в информационных } \\
\text { системах (с использованием новых информационных } \\
\text { технологий) и пр. }\end{array}$ \\
\hline
\end{tabular}




\begin{tabular}{|c|c|}
\hline ГФК & Наименование НПА \\
\hline Уровень объектов ГФК & $\begin{array}{l}\text { На наш взгляд, в настоящее время выражен в } \\
\text { ответвлении ГФК в форме внутреннего финансового } \\
\text { контроля, внутреннего финансового аудита } \\
\text { (система правового регулирования ВФК, ВФА } \\
\text { формируется на законодательном, подзаконном } \\
\text { уровне, уровне контрольного органа и на } \\
\text { законодательном и подзаконном уровнях, а также } \\
\text { уровнях контрольного органа и администратора } \\
\text { бюджетных средств) }\end{array}$ \\
\hline Цель проведения ГФК (предмет контроля) & $\begin{array}{l}\text { Ст. } 265 \text { БК РФ - обеспечение соблюдения положений } \\
\text { правовых актов, регулирующих бюджетные } \\
\text { правоотношения, правовых актов, обусловливающих } \\
\text { публичные нормативные обязательства и } \\
\text { обязательства по иным выплатам физическим } \\
\text { лицам из бюджетов бюджетной системы Российской } \\
\text { Федерации, а также соблюдения условий } \\
\text { государственных (муниципальных) контрактов, } \\
\text { договоров (соглашений) о предоставлении средств из } \\
\text { бюджета }\end{array}$ \\
\hline Органы ГФК & $\begin{array}{l}\text { 1. Федеральное казначейство (его территориальные } \\
\text { органы). } \\
\text { 2. Органы государственного (муниципального) } \\
\text { контроля субъектов РФ }\end{array}$ \\
\hline Принципы правового регулирования & $\begin{array}{l}\text { П. } 2 \text { Постановления № } 1092 \text { - законности, } \\
\text { объективности, эффективности, независимости, } \\
\text { профессиональной компетентности, достоверности } \\
\text { результатов и гласности }\end{array}$ \\
\hline $\begin{array}{l}\text { Принципы, на которых основывается } \\
\text { деятельность должностных лиц органов ГФК }\end{array}$ & $\begin{array}{l}\text { Федеральный стандарт № } 95 \text { - этические } \\
\text { принципы, принципы независимости, } \\
\text { объективности, профессиональной компетентности, } \\
\text { целеустремленности, достоверности, } \\
\text { профессионального скептицизма }\end{array}$ \\
\hline Объекты ГФК & $\begin{array}{l}\text { Ст. } 266.1 \text { БК РФ, п. } 7 \text { Постановления № } 1092 \text { - главные } \\
\text { администраторы бюджетных средств, финансовые } \\
\text { органы, государственные учреждения и пр. }\end{array}$ \\
\hline Методы ГФК & $\begin{array}{l}\text { Ст. } 267.1 \text { БК РФ, п. } 3 \text { Постановление № 1092, } \\
\text { п. } 2 \text { Федерального стандарта № } 95 \text { - проверка, } \\
\text { ревизия, обследование; бюджетный мониторинг }\end{array}$ \\
\hline Полномочия органов ГФК & Ст. 269.2 БК РФ \\
\hline $\begin{array}{l}\text { Общие требования к проведению контрольных } \\
\text { мероприятий }\end{array}$ & Постановление № 1092 \\
\hline $\begin{array}{l}\text { Права и обязанности органов ГФК, требования } \\
\text { к должностным лицам органов контроля }\end{array}$ & Федеральный стандарт № 100 \\
\hline
\end{tabular}

В настоящее время проводится комплекс мероприятий по реформированию внутреннего ГФК, который в первую очередь должен сделать прозрачной систему правового регулирования внутреннего ГФК как для адресатов норм (администраторов бюджетных средств), так и для общества в целом. На следующем этапе необходимо проанализировать своего рода «ответ-

6 В настоящее время, на наш взгляд, в системе ГФК формируется уровень регулирования объектов ГФК в форме ответвления ВФК и ВФА. 
вление внутреннего ГФК» в форме внутреннего финансового контроля (ВФК) и внутреннего финансового аудита (ВФА).

\section{2. Внутренний финансовый контроль (ВФК) и внутренний финансовый аудит (ВФА).}

15 апреля 2014 г. постановлением Правительства РФ была утверждена государственная программа Российской Федерации «Управление государственными финансами и регулирование финансовых рынков» ${ }^{7}$. Этим программным документом были определены цели и задачи реформирования управления общественными (государственными и муниципальными) финансами, в котором особое место отводилось вопросам совершенствования системы ГФК.

В паспорте подпрограммы 2 «Повышение качества управления бюджетным процессом» целью подпрограммы были названы цифровизация и повышение качества планирования и исполнения федерального бюджета, кассового обслуживания исполнения бюджетов бюджетной системы Российской Федерации и формирования бюджетной отчетности, системы контроля в финансово-бюджетной срере; развитие контрактной системы в сфере закупок. Как видно из цели подпрограммы, стержневым вопросом является контроль, который, в свою очередь, выступает неотьемлемой частью качественного управления в сфере финансов. Сформулированные в подпрограмме задачи подтверждают значимость организации системы контроля в финансово-бюджетной сфере.

Одной из задач подпрограммы 2 названо совершенствование методологической базы осуществления внутреннего государственного (муниципального) финансового контроля и методического обеспечения деятельности в области внутреннего финансового контроля и внутреннего финансового аудита.
Постановлением Правительства РФ от 17.03.2014 № $193^{8}$, которое утратило силу с 1 января 2020 г., были утверждены Правила осуществления главными распорядителями (распорядителями) средств федерального бюджета (бюджета государственного внебюджетного фонда Российской Федерации), главными администраторами (администраторами) доходов федерального бюджета (бюджета государственного внебюджетного фонда Российской Федерации), главными администраторами (администраторами) источников финансирования дефицита федерального бюджета (бюджета государственного внебюджетного фонда Российской Федерации) внутреннего финансового контроля и внутреннего финансового аудита9. Так, данными Правилами был утвержден порядок осуществления полномочий по внутреннему финансовому контролю и внутреннему финансовому аудиту для главных администраторов бюджетных средств, осуществляющих различные процедуры и операции со средствами федерального бюджета. Таким образом, ВФК и ВФА осуществлялись в соответствии с порядком, устанавливаемым соответственно Правительством РФ, высшим исполнительным органом государственной власти субъекта Российской Федерации, местной администрацией. Высшие исполнительные органы государственной власти субъектов Российской Федерации и местные администрации были уполномочены на самостоятельную организацию деятельности по осуществлению внутреннего финансового контроля и внутреннего финансового аудита путем издания собственных порядков. Однако зачастую положения названных Правил ими просто копировались.

Постановлением Правительства РФ от 11.02.2017 № 174 «О внесении изменения в Типовой регламент внутренней организации федеральных органов исполнительной власти ${ }^{10}$ пункт 1.10 Типового регламента внутренней

7 СЗ РФ. 2014. № 18 (ч. ІІІ). СТ. 2166.

8 В соответствии с п. 5 ст. 160.2-1 БК РФ с 1 января 2020 г. внутренний финансовый аудит осуществляется в соответствии с федеральными стандартами внутреннего финансового аудита.

9 Доступ из СПС «КонсультантПлюс» (дата обращения: 11.05.2020).

10 СЗ РФ. 2017. № 9. СТ. 1357. 
организации федеральных органов исполнительной власти, утвержденного постановлением Правительства РФ от 28.07.2005 № 452 «О Типовом регламенте внутренней организации федеральных органов исполнительной власти» ${ }^{11}$, был дополнен словами «организацию и осуществление внутреннего финансового контроля и внутреннего финансового аудита в федеральном органе исполнительной власти». Таким образом, с учетом внесенных изменений руководитель федерального органа исполнительной власти несет персональную ответственность за организацию и осуществление ВФК и ВФА в органе исполнительной власти.

Oтсутствие строгой регламентации этой сореры деятельности порождало непонимание и зачастую путаницу в соотношении понятий внутреннего ГФК, ВФК и ВФА. По сути, все эти сферы контрольной деятельности (с различными подходами и инструментами, формами и методами осуществления) были направлены на достижение одних целей с точки зрения системы управления государственными финансами.

В целях обеспечения единообразного подхода к осуществлению главными администраторами бюджетных средств внутреннего финансового контроля, с целью разъяснения положений ст. 160.2-1 БК РФ, из которой следует обязательность проведения администратором бюджетных средств ВФК, Минфином России были разработаны и утверждены приказом от 07.09.2016 № $356^{12}$ методические рекомендации по осуществлению внутреннего финансового контроля (далее - Методические рекомендации № 356). В соответствии с приказом Минфина России от 30.04.2020 № 186 документ уже утратил силу.

В Методических рекомендациях № 356 внутренний финансовый контроль определялся как непрерывный процесс, реализуемый руководителем главного администратора бюджетных средств и должностными лицами его структурных подразделений, а также должностными лицами иных подразделений государственного органа, которые организуют и выполняют, а также обеспечивают соблюдение внутренних процедур составления и исполнения бюджета, ведения бюджетного учета и составления бюджетной отчетности.

ВФК является финансовым контролем, поэтому на практике вся ответственность за исполнение бюджетных процедур «перекладывается» на финансовые и бухгалтерские подразделения. Если рассмотреть бюджетные процедуры в виде процесса и наложить процесс на организационную структуру главных распорядителей (администраторов) бюджетных средств, окажется, что почти все структурные подразделения участвуют в осуществлении бюджетных процедур. Поэтому ВФК находится в ве́дении не только финансовых и бухгалтерских служб. В первую очередь слово «финансовый» подчеркивает характер видов деятельности, подлежащих проверке, а слово «контроль» обозначает функцию управления. И эта функция охватывает все инструменты, позволяющие руководителю контролировать качество «управления» государственными финансами.

Отметим, что обязательность внутреннего финансового контроля совершаемых фактов хозяйственной жизни определена статьей 19 Федерального закона от 06.12.2011 № 402-Ф3 и распространяется также на государственные органы, организации (администраторов бюджетных средств) с оговоркой, установленной в п. 3 ст. 19 указанного Закона, о применении «с учетом норм бюджетного законодательства». В этой связи распространение указанной нормы Закона о внутреннем контроле фактов хозяйственной деятельности на государственные органы и организации представляется излишним.

Организация работы внутреннего финансового контроля и внутреннего финансового аудита требует определенных административных усилий, а также подготовки большого числа ведомственных актов, разъясняющих процедурные вопросы.

Поскольку Методические рекомендации № 356н были отменены приказом Минфина России от 30.04.2020 № 186, возникает вопрос: в соответствии с какими документами подзакон-

11 С3 РФ. 2005. № 31. СТ. 3233.

12 Доступ из СПС «КонсультантПлюс» (дата обращения: 11.05.2020). 
ного уровня организовать ВФК администратору бюджетных средств? Представляется верным организовать ВФК администратору бюджетных средств самостоятельно в целях реализации риск-ориентированного подхода, закрепив такое полномочие на законодательном уровне.

Минфином России также были разработаны и утверждены приказом от 30.12.2016 № $822^{13}$ Методические рекомендации по осуществлению внутреннего финансового аудита (далее Методические рекомендации № 822). Отметим, что Методические рекомендации № 822 также упразднены приказом Минфина России от 30.04.2020 № 186. В соответствии со ст. 160.2-1 БК РФ, ВФА являлся деятельностью по формированию и предоставлению независимой и объективной информации о результатах исполнения бюджетных полномочий главным администратором бюджетных средств, которая, в свою очередь, направлена на повышение качества осуществления внутренних бюджетных процедур. Кроме того, Методическими рекомендациями № 822 определялся объект и субъект внутреннего финансового аудита, а также принципы, на которых основывается деятельность субъектов внутреннего финансового аудита: законности, объективности, эффективности, независимости, профессиональной компетентности, а также системности и ответственности.

Однако следует отметить, что рассмотренные методические рекомендации Минфина России носили рекомендательный характер и не подразумевали применения различных видов санкций в случае неисполнения отдельных положений, установленных данными актами.

Одним из реальных шагов в реализации государственной программы Российской Федерации стало принятие Федерального закона от 26.07.2019 № 199-Ф3 «О внесении изменений в Бюджетный кодекс Российской Федерации в части совершенствования государственного (муниципального) финансового контроля, внутреннего финансового контроля и внутреннего финансового аудита», которым были внесены изменения в ст. 160.2-1 «Бюджетные полномочия отдельных участников бюджетного процесса по организации и осуществлению внутреннего финансового аудита». В статье 160.2-1 БК РФ, которая, в отличие от всех методических рекомендаций Минфина России ${ }^{14}$, имеет обязательный характер, закреплены полномочия отдельных участников бюджетного процесса по организации и осуществлению внутреннего финансового аудита, а ВФА определяется как деятельность по формированию и предоставлению руководителю главного администратора бюджетных средств, руководителю распорядителя бюджетных средств, руководителю получателя бюджетных средств, руководителю администратора доходов бюджета, руководителю администратора источников финансирования дефицита бюджета:

1) информации о результатах оценки исполнения бюджетных полномочий распорядителя бюджетных средств, получателя бюджетных средств, администратора доходов бюджета, администратора источников финансирования дефицита бюджета (далее - администратор бюджетных средств), главного администратора бюджетных средств, в том числе заключения о достоверности бюджетной отчетности;

2) предложений о повышении качества финансового менеджмента, в том числе о повышении результативности и экономности использования бюджетных средств;

3) заключения о результатах исполнения решений, направленных на повышение качества финансового менеджмента.

В соответствии со ст. 160.2-1 БК РФ, ВФА осуществляется в целях: «1) оценки надежности внутреннего процесса главного администрато-

13 Доступ из СПС «КонсультантПлюс» (дата обращения: 11.05.2020).

14 Минфин России, в соответствии со ст. 165 БК РФ, осуществляет нормативное и методическое обеспечение осуществления (анализа осуществления) внутреннего финансового аудита, проведения финансовыми органами (органами управления государственными внебюджетными фондами), главными администраторами бюджетных средств мониторинга качества финансового менеджмента, а также осуществляет методическое обеспечение осуществления внутреннего финансового контроля. 
ра бюджетных средств, администратора бюджетных средств, осуществляемого в целях соблюдения установленных правовыми актами, регулирующими бюджетные правоотношения, требований к исполнению своих бюджетных полномочий (далее - внутренний финансовый контроль), и подготовки предложений об организации внутреннего финансового контроля; 2) подтверждения достоверности бюджетной отчетности и соответствия порядка ведения бюджетного учета единой методологии бюджетного учета, составления, представления и утверждения бюджетной отчетности, установленной Министерством финансов Российской Федерации, а также ведомственным (внутренним) актам, принятым в соответствии с пунктом 5 статьи 264.1 БК РФ; 3) повышения качества финансового менеджмента».

В соответствии с внесенными в БК РФ изменениями самостоятельное бюджетное полномочие главного администратора (администратора) бюджетных средств по осуществлению внутреннего финансового контроля исключено из БК РФ.

Согласно разъяснениям Минфина России от 03.12.2019, ВФК, определяемый в качестве внутреннего процесса главного администратора (администратора) бюджетных средств и осуществляемый в целях соблюдения установленных правовыми актами, регулирующими бюджетные правоотношения, требований к исполнению бюджетных полномочий, не отменен и должен осуществляться. При этом ВФК является составной частью каждого бюджетного полномочия главного администратора (администратора) бюджетных средств, то есть ВФК как контрольный механизм осуществляется всегда, в ходе формирования любого юридически значимого документа и (или) совершения операций, действий, направленных на выполнение бюджетного полномочия. Из этого следует, что главный администратор (администратор) бюджетных средств самостоятельно определяет порядок осуществления внутреннего финансового контроля с учетом необходимости соблюдения требования к исполнению бюджетных полно- мочий. С 1 января 2020 г. в части правового регулирования осуществления ВФК исключается обязанность главных администраторов (администраторов) бюджетных средств по изданию нормативных правовых актов по ВФК, однако главные администраторы (администраторы) бюджетных средств вправе издать ведомственные (внутренние) акты, обеспечивающие осуществление внутреннего финансового контроля, или продолжить пользоваться ранее изданными ведомственными (внутренними) актами ${ }^{15}$.

Таким образом, ВФК в первую очередь направлен на соблюдение нормативных правовых (правовых) актов, регламентирующих составление и исполнение бюджета, бюджетной отчетности и ведение бюджетного учета, а также на реализацию мер по повышению результативности и экономности использования бюджетных средств. ВФА, в свою очередь, оценивает надежность ВФК и реализуется в целях повышения эффективности внутреннего финансового контроля, а также подтверждения достоверности бюджетной отчетности, установления соответствия порядка ведения бюджетного учета единой методологии и повышения качества финансового менеджмента.

ВФА осуществляется на основе принципа функциональной независимости структурными подразделениями или в случаях, предусмотренных федеральными стандартами внутреннего финансового аудита, уполномоченными должностными лицами (работниками) главного администратора бюджетных средств, администратора бюджетных средств, наделенными полномочиями по осуществлению ВФА, а в случаях передачи полномочий, предусмотренных ст. 160.2-1. БК РФ, - структурными подразделениями или уполномоченными должностными лицами (работниками) главного администратора бюджетных средств (администратора бюджетных средств), которому передаются указанные полномочия.

Учитывая, что в процессе реформирования Методические рекомендации № 822 были отменены приказом Минфина России от 30.04.2020

15 Письмо Минфина России от 03.12.2019 № 02-02-05/93929 // Доступ из СПС «КонсультантПлюс» (дата обращения: 13.05.2020). 
№ 186, ВФА осуществляется в соответствии с федеральными стандартами внутреннего финансового аудита. На сегодняшний день Минфином России разработаны три федеральных стандарта внутреннего финансового аудита (далее - ФС ВФА):

1) «Основания и порядок организации, случаи и порядок передачи полномочий по осуществлению внутреннего финансового аудита», утвержден приказом Минфина России от 18.12.2019 № 237н: установлены основания и порядок организации ВФА, порядок передачи полномочий по осуществлению ВФА, установлено также, что руководитель главного администратора (администратора) бюджетных средств единолично несет ответственность за организацию ВФА;

2) «Определения, принципы и задачи внутреннего финансового аудита», утвержден приказом Минфина России от 21.11.2019 № 196н: закреплены термины ВФА и их определения, принципы ВФА, задачи ВФА;

3) «Права и обязанности должностных лиц (работников) при осуществлении внутреннего финансового аудита», утвержден приказом Минфина России от 21.11.2019 № $195 \mathrm{H}^{16}$ : закреплены права и обязанности должностных лиц (работников) субъекта ВФА, права и обязанности субъектов бюджетных процедур.

Для понимания сути ВФА важно обращаться к содержанию этих федеральных стандартов, а для лиц, осуществляющих внутренний финансовый аудит, они служат ориентирами для последовательного осуществления поставленных в стандартах задач и определяют пошагово все процедурные вопросы.

В ФС ВФА «Определения, принципы и задачи внутреннего финансового аудита» приведены соответствующие термины и определения. В частности:

- субъект внутреннего финансового аудита структурное подразделение или уполномоченное должностное лицо (работник) главного администратора (администратора) бюджетных средств, наделенное полномочиями по осуществлению внутреннего финансового аудита;

- руководитель субъекта внутреннего финансового аудита - руководитель структурного подразделения, наделенного полномочиями по осуществлению внутреннего финансового аудита, а в случае отсутствия такого структурного подразделения - уполномоченное должностное лицо (работник) главного администратора (администратора) бюджетных средств, наделенное полномочиями по осуществлению внутреннего финансового аудита (далее - уполномоченное должностное лицо);

- бюджетные процедуры - процедуры главного администратора (администратора) бюджетных средств, результат выполнения которых влияет на значения показателей качества финансового менеджмента, определяемые в соответствии с порядком проведения мониторинга качества финансового менеджмента, предусмотренным пунктом 6 ст. 160.2-1 БК РФ (далее - значения показателей качества финансового менеджмента), в том числе процедуры по составлению и представлению сведений, необходимых для составления проекта бюджета, а также по исполнению бюджета, ведению бюджетного учета и составлению бюджетной отчетности; - объект внутреннего финансового аудита бюджетная процедура и (или) составляющие эту процедуру операции (действия) по выполнению бюджетной процедуры;

- субъекты бюджетных процедур - руководитель (заместители руководителя), руководители и должностные лица (работники) структурных подразделений главного администратора (администратора) бюджетных средств, которые организуют (обеспечивают выполнение), выполняют бюджетные процедуры;

- метод внутреннего финансового аудита прием, применяемый при проведении аудиторского мероприятия членами аудиторской группы или уполномоченным должностным

16 Доступ из СПС «КонсультантПлюс» (дата обращения: 14.05.2020). 
лицом, в зависимости от целей и задач аудиторского мероприятия, результатов оценки бюджетных рисков, степени обеспеченности ресурсами (временны́ми, трудовыми, материальными, финансовыми и иными ресурсами, которые способны оказать влияние на качество проведения аудиторского мероприятия) и др.

К методам ВФА отнесены аналитические процедуры, инспектирование, пересчет, запрос, подтверждение, наблюдение, мониторинг процедур внутреннего финансового контроля.

По сравнению с Методическими рекомендациями № 822 расширен список принципов ВФА - добавились принципы профессионального скептицизма ${ }^{17}$, системности ${ }^{18}$, стандартизации ${ }^{19}$.
Деятельность субъекта внутреннего финансового аудита и членов аудиторской группы основывается на принципах законности ${ }^{20}$, функциональной независимости ${ }^{21}$, объективности $^{22}$, компетентности ${ }^{23}$, профессионального скептицизма, системности, эффективности ${ }^{24}$, ответственности ${ }^{25}$ и стандартизации.

Пунктом 5 ст. 160.2-1 БК РФ устанавливаются базовые требования к ФС ВФА.

Во-первых, ФС ВФА должны содержать принципы, в том числе принцип функциональной независимости, задачи, основания и порядок организации, планирования и проведения внутреннего финансового аудита, реализации его результатов, права и обязанности должностных лиц (работников) при осуществлении внутреннего финансового аудита, а также определять

17 Принцип профессионального скептицизма подразумевает критическую оценку обоснованности, надежности и достаточности полученных аудиторских доказательств и направлен на минимизацию возможности упустить из виду подозрительные обстоятельства, сделать неоправданные обобщения при подготовке выводов, использовать ошибочные допущения при определении характера, временны́х рамок и объема аудиторских процедур, а также при оценке их результатов.

18 Принцип системности заключается в том, что при планировании и проведении аудиторских мероприятий бюджетные и коррупционные риски периодически анализируются по всем бюджетным процедурам.

19 Принцип стандартизации означает, что ВФА осуществляется в соответствии с федеральными стандартами внутреннего финансового аудита, а также ведомственными (внутренними) актами, обеспечивающими осуществление внутреннего финансового аудита с соблюдением федеральных стандартов внутреннего финансового аудита.

20 Принцип законности выражается в строгом и полном соблюдении законодательства Российской Федерации, а также правовых актов, регулирующих организацию и осуществление внутреннего финансового аудита, включая федеральные стандарты внутреннего финансового аудита и ведомственные (внутренние) акты главного администратора (администратора) бюджетных средств.

21 Принцип функциональной независимости означает отсутствие условий, которые создают угрозу способности субъекта внутреннего финансового аудита беспристрастно и объективно выполнять свои обязанности.

22 Принцип объективности выражается в беспристрастности, в том числе в недопущении конфликта интересов любого рода, при планировании и проведении аудиторских мероприятий, а также при формировании заключений и годовой отчетности о результатах деятельности субъекта внутреннего финансового аудита.

23 Принцип компетентности выражается в применении субъектом внутреннего финансового аудита совокупности профессиональных знаний, навыков и других компетенций, позволяющих осуществлять ВФА.

24 Принцип эффективности означает, что планирование и проведение аудиторских мероприятий должны быть основаны на необходимости достижения целей осуществления внутреннего финансового аудита и обеспечения полноты заключения о результатах проведения аудиторского мероприятия путем использования заданного (наименьшего) объема затрачиваемых ресурсов.

25 Принцип ответственности означает, что субъект внутреннего финансового аудита несет ответственность перед руководителем главного администратора (администратора) бюджетных средств за предоставле- 
случаи и порядок передачи полномочий по осуществлению внутреннего финансового аудита.

Во-вторых, главные администраторы бюджетных средств, администраторы бюджетных средств, осуществляющие ВФА, наделены правом издавать ведомственные (внутренние) акты, обеспечивающие осуществление внутреннего финансового аудита с соблюдением федеральных стандартов внутреннего финансового аудита.

Отметим, что пунктом 6 ст. 160.2-1 БК РФ также установлен мониторинг качества финансового менеджмента, включающий мониторинг качества исполнения бюджетных полномочий, а также качества управления активами, осуществления закупок товаров, работ и услуг для обеспечения государственных (муниципальных) нужд. Мониторинг проводится:

1) финансовым органом (органом управления государственным внебюджетным фондом) в установленном им порядке в отношении главных администраторов средств соответствующего бюджета;

2) главным администратором бюджетных средств в установленном им порядке в отношении подведомственных ему администраторов бюджетных средств.

Порядок проведения мониторинга качества финансового менеджмента определяет в том числе: 1) правила расчета и анализа значений показателей качества финансового менеджмента, формирования и представления информации, необходимой для проведения указанного мониторинга; 2) правила формирования и представления отчета о результатах мониторинга качества финансового менеджмента.

Главный администратор средств соответствующего бюджета вправе внести на рассмотрение финансового органа (органа управления государственным внебюджетным фондом) предложение о передаче полномочий по проведению мониторинга качества финансового менеджмента в отношении подведомственных ему администраторов бюджетных средств и по согласованию с финансовым органом (органом управления государственным внебюджетным фондом) передать этому финансовому органу (органу управления государственным внебюджетным фондом) указанные полномочия.

Все методические рекомендации Минфина России не содержат обязательных требований, не устанавливают правовых норм, носят рекомендательный характер и могут учитываться при проведении мониторинга качества финансового менеджмента, в том числе могут быть использованы при подготовке нормативных правовых актов и ведомственных (внутренних) актов, определяющих порядок проведения мониторинга качества финансового менеджмента. Не являются исключением и Методические рекомендации по проведению мониторинга качества финансового менеджмента (приказ Минфина России от 14.11.2019 № 1031). Они направлены на оказание финансовым органам (органам управления государственными внебюджетными фондами) и главным администраторам бюджетных средств, которые проводят мониторинг качества финансового менеджмента, содействия по вопросам проведения такого мониторинга, разработки порядка его проведения, а также определения случаев и порядка передачи полномочий по проведению мониторинга качества финансового менеджмента.

Минфин России предлагает понимать под финансовым менеджментом организацию и исполнение распорядителем бюджетных средств, получателем бюджетных средств, администратором доходов бюджета, администратором источников финансирования дефицита бюджета (далее - администратор бюджетных средств), главным администратором бюджетных средств, финансовым органом (органом управления государственным внебюджетным фондом) бюджетных процедур в целях исполнения бюджетных полномочий. В свою очередь, под бюджетными процедурами понимаются процедуры, результат выполнения которых влияет на значения показателей качества финансового менеджмента, в том числе процедуры по составлению и представлению сведений,

ние полных и достоверных заключений, выводов и предложений (рекомендаций), позволяющих при их надлежащем выполнении достичь цели и задачи осуществления внутреннего финансового аудита. 
необходимых для составления проекта бюджета, а также по исполнению бюджета, ведению бюджетного учета и составлению бюджетной отчетности. Отметим, что понятие бюджетных рисков, бюджетных процедур уже приведено в ФС ВФА. Наличие дублирующих норм также усложняет понимание при правоприменении. Статьей 157 «Бюджетные полномочия органов государственного (муниципального) финансового контроля» БК РФ Федеральное казначейство наделено компетентными полномочиями. Так, Федеральное казначейство проводит анализ осуществления главными администраторами бюджетных средств внутреннего финансового аудита в целях подготовки предложений по совершенствованию осуществления указанными главными администраторами бюджетных средств внутреннего финансового аудита ${ }^{26}$.

Согласно приказу Минфина России от 27.12.2019 № 1657 «Об утверждении методики проведения анализа осуществления главными администраторами бюджетных средств внутреннего финансового аудита» ${ }^{27}$, названная методика предназначена для обеспечения проведения Федеральным казначейством предусмотренного пунктом 4 ст. 157 БК РФ анализа осуществления главными администраторами бюджетных средств внутреннего финансового аудита.

Целью анализа названа подготовка предложений по совершенствованию осуществления главными администраторами бюджетных средств внутреннего финансового аудита. Задачами анализа определены: выявление лучших практик организации и осуществления внутреннего финансового аудита; выявление типовых недостатков и (или) нарушений при организации и осуществлении внутреннего финансового аудита, в том числе их причин и условий; анализ результатов проведения глав- ными администраторами бюджетных средств внутреннего финансового аудита, в том числе изучение заключений и годовой отчетности о результатах деятельности субъектов внутреннего финансового аудита; оценка состояния внутреннего финансового аудита, осуществляемого главными администраторами бюджетных средств; представление в Минфин России информации и документов, необходимых для совершенствования нормативного и методического обеспечения осуществления внутреннего финансового аудита.

Согласно этой методике Федеральное казначейство после окончания аналитического мероприятия в отношении главных администраторов средств федерального бюджета и в дополнение к формированию аналитического отчета направляет в Минфин России в срок до 1 сентября текущего финансового года результаты оценки осуществления главными администраторами средств федерального бюджета внутреннего финансового аудита в отчетном финансовом году ${ }^{28}$, которые необходимы для расчета показателей качества финансового менеджмента, характеризующих ВФА, проведенный администраторами средств федерального бюджета.

Федеральное казначейство также после окончания аналитического мероприятия в отношении главных администраторов средств бюджета субъекта Российской Федерации (местного бюджета), осуществляющих деятельность на территории субъекта Российской Федерации, направляет в финансовый орган субъекта Российской Федерации информацию об осуществлении главными администраторами бюджетных средств внутреннего финансового аудита в субъекте Российской Федерации, в том числе: результаты анкетирования; перечень главных администраторов бюджетных средств, в отношении которых проведено аналитическое

26 Приказ Казначейства России от 13.02.2020 № 8н «О признании утратившим силу приказа Федерального казначейства от 23.06.2017 № 16н “Об утверждении Порядка проведения анализа осуществления главными администраторами средств федерального бюджета внутреннего финансового контроля и внутреннего финансового аудита"» (зарегистрирован в Минюсте России 19.03.2020 № 57785).

27 Документ не был опубликован. Доступ из СПС «КонсультантПлюс» (дата обращения: 17.05.2020).

28 В том числе сводный рейтинг главных администраторов средств федерального бюджета по организации и осуществлению внутреннего финансового аудита. 
мероприятие; информацию о недостатках, отраженных в аналитическом отчете и наиболее характерных для главных администраторов бюджетных средств, действующих на территории субъекта Российской Федерации.

В свою очередь, государственная программа Российской Федерации «Управление государственными финансами и регулирование фи- нансовых рынков», конечно же, предполагает строгую и системную реализацию поставленных задач.

Таким образом, с учетом обзора и анализа документов разного уровня, была структурирована система правового регулирования и проведен сравнительный анализ ВФК, ВФА (табл. 2).

Система правового регулирования и сравнительный анализ ВФА, ВФК

\begin{tabular}{|c|c|c|}
\hline Наименование & ВФА & ВФК \\
\hline Законодательный уровень & \multicolumn{2}{|c|}{$\begin{array}{l}\text { Статья 160.2-1 БК РФ (ВФА осуществляется в целях определения } \\
\text { надежности ВФК («контроль над контролерами») }\end{array}$} \\
\hline & & $\begin{array}{l}\text { Ст. } 19 \text { Федерального закона } \\
\text { от 06.12.2011 № 402-Ф3 } \\
\text { «О бухгалтерском учете» } \\
\text { (распространяется на } \\
\text { государственные органы и } \\
\text { организации) }\end{array}$ \\
\hline Подзаконный уровень & $\begin{array}{l}\text { 1. Федеральный стандарт } \\
\text { «Основания и порядок } \\
\text { организации, случаи и порядок } \\
\text { передачи полномочий по } \\
\text { осуществлению внутреннего } \\
\text { финансового аудита», утв. } \\
\text { приказом Минфина России от } \\
\text { 18.12.2019 № 237н. } \\
\text { 2. Федеральный стандарт } \\
\text { «Определения, принципы } \\
\text { и задачи внутреннего } \\
\text { финансового аудита», утв. } \\
\text { приказом Минфина России от } \\
\text { 21.11.2019 № 196н. } \\
\text { 3. Федеральный стандарт } \\
\text { «рава и обязанности } \\
\text { должностных лиц (работников) } \\
\text { при осуществлении внутреннего } \\
\text { финансового аудита», утв. } \\
\text { приказом Минфина России от } \\
\text { 21.11.2019 № } 195 н . \\
\text { 4. Приказ Минфина России } \\
\text { № 1031 от 14.11.2019 «Об } \\
\text { утверждении Методических } \\
\text { рекомендации по проведению } \\
\text { мониторинга качества } \\
\text { финансового менеджмента». } \\
\text { 5. Приказ Минфина России } \\
\text { № 1657 от 27.12.2019 «Об } \\
\text { утверждении Методики } \\
\text { проведения анализа } \\
\text { осуществления главными } \\
\text { администраторами бюджетных } \\
\text { средств внутреннего финансового } \\
\text { аудита» }\end{array}$ & \\
\hline
\end{tabular}




\begin{tabular}{|c|c|c|}
\hline Наименование & ВФА & ВФК \\
\hline $\begin{array}{l}\text { Уровень государственного органа } \\
\text { (организации) }\end{array}$ & $\begin{array}{l}\text { Локальные нормативные акты, } \\
\text { изданные в соответствии с } \\
\text { законодательным и подзаконным } \\
\text { уровнями регулирования }\end{array}$ & $\begin{array}{l}\text { Локальные нормативные } \\
\text { акты, изданные в соответствии } \\
\text { с законодательным и } \\
\text { подзаконным уровнями } \\
\text { регулирования }\end{array}$ \\
\hline Понятие ВФА/ВФК & $\begin{array}{l}\text { Ст. 160.2-1 БК РФ: «деятельность } \\
\text { по формированию и } \\
\text { предоставлению руководителю } \\
\text { государственного органа } \\
\text { (организации): } \\
\text { 1) информации о результатах } \\
\text { оценки исполнения бюджетных } \\
\text { полномочий, в том числе } \\
\text { заключения о достоверности } \\
\text { бюджетной отчетности; } \\
\text { 2) предложений о повышении } \\
\text { качества финансового } \\
\text { менеджмента, в том числе о } \\
\text { повышении результативности } \\
\text { и экономности использования } \\
\text { бюджетных средств; } \\
\text { 3) заключения о результатах } \\
\text { исполнения решений, } \\
\text { направленных на повышение } \\
\text { качества финансового } \\
\text { менеджмента» }\end{array}$ & $\begin{array}{l}\text { Ст. 160.2-1 БК РФ: «оценка } \\
\text { надежности внутреннего } \\
\text { процесса главного } \\
\text { администратора бюджетных } \\
\text { средств, администратора } \\
\text { бюджетных средств, } \\
\text { осуществляемого в целях } \\
\text { соблюдения установленных } \\
\text { правовыми актами, } \\
\text { регулирующими бюджетные } \\
\text { правоотношения, требований к } \\
\text { исполнению своих бюджетных } \\
\text { полномочий» }\end{array}$ \\
\hline Цель проведения & $\begin{array}{l}\text { П. } 2 \text { ст. 160.2-1 БК РФ: } \\
\text { «оценка надежности } \\
\text { внутреннего финансового } \\
\text { контроля и подготовка } \\
\text { рекомендаций по повышению } \\
\text { его эффективности; } \\
\text { подтверждение достоверности } \\
\text { бюджетной отчетности и } \\
\text { соответствия порядка ведения } \\
\text { бюджетного учета методологии } \\
\text { и стандартам бюджетного учета, } \\
\text { установленным Министерством } \\
\text { финансов Российской } \\
\text { Федерации; } \\
\text { подготовка предложений по } \\
\text { повышению экономности и } \\
\text { результативности использования } \\
\text { бюджетных средств» }\end{array}$ & $\begin{array}{l}\text { В настоящее время не } \\
\text { установлена НПА. } \\
\text { До } 30 \text { апреля } 2020 \text { г. - п. } 2 \\
\text { Методических рекомендаций } \\
\text { № 356: } \\
\text { соблюдение внутренних } \\
\text { стандартов и процедур } \\
\text { составления и исполнения } \\
\text { бюджета бюджетов РФ; } \\
\text { подготовка и организация мер } \\
\text { по повышению экономности и } \\
\text { результативности использования } \\
\text { бюджетных средств; } \\
\text { соблюдение установленных } \\
\text { внутренних стандартов и } \\
\text { процедур составления и } \\
\text { исполнения бюджета по } \\
\text { доходам, расходам, источникам } \\
\text { финансирования дефицита } \\
\text { бюджета, составления } \\
\text { бюджетной отчетности и } \\
\text { ведения бюджетного учета }\end{array}$ \\
\hline Принципы & $\begin{array}{l}\text { Общий принцип функциональной } \\
\text { независимости - п. } 3 \\
\text { ст. 160.2-1 БК РФ, ФС ВФА } \\
\text { от 21.11.2019 № 196н: } \\
\text { принципы профессионального } \\
\text { скептицизма, системности, } \\
\text { эффективности, ответственности } \\
\text { и стандартизации }\end{array}$ & $\begin{array}{l}\text { Не установлены НПА, } \\
\text { до } 30 \text { апреля } 2020 \text { г. - } \\
\text { п. } 4 \text { Методических } \\
\text { рекомендаций № } 356: \\
\text { законности, объективности } \\
\text { и профессиональной } \\
\text { компетентности, системности, } \\
\text { надежности (эффективности), } \\
\text { ответственности }\end{array}$ \\
\hline
\end{tabular}




\begin{tabular}{|c|c|c|}
\hline Наименование & ВФА & ВФК \\
\hline Субъект ВФА/ВФК & $\begin{array}{l}\text { ФС ВФА от 18.12.2019 № 237н: } \\
\text { структурное подразделение } \\
\text { или уполномоченное } \\
\text { должностное лицо (работник) } \\
\text { главного администратора } \\
\text { (администратора) бюджетных } \\
\text { средств, наделенное } \\
\text { полномочиями по } \\
\text { осуществлению внутреннего } \\
\text { финансового аудита }\end{array}$ & $\begin{array}{l}\text { Не установлен НПА до } \\
30 \text { апреля } 2020 \text { г. - ст. } 6 \\
\text { Методических рекомендаций } \\
\text { № 356: руководитель } \\
\text { (заместитель руководителя) } \\
\text { главного администратора } \\
\text { (администратора) бюджетных } \\
\text { средств; } \\
\text { руководители и иные } \\
\text { должностные лица } \\
\text { уполномоченных подразделений } \\
\text { главного администратора } \\
\text { (администратора) бюджетных } \\
\text { средств, а также должностные } \\
\text { лица иных подразделений } \\
\text { государственного органа (органа } \\
\text { местного самоуправления), } \\
\text { уполномоченные на } \\
\text { осуществление операций } \\
\text { (действий по формированию } \\
\text { документов, необходимых } \\
\text { для выполнения внутренних } \\
\text { бюджетных процедур) }\end{array}$ \\
\hline Объект & $\begin{array}{l}\text { ФС ВФА от 21.11.2019 № 196н: } \\
\text { бюджетная процедура и (или) } \\
\text { составляющие эту процедуру } \\
\text { операции по выполнению } \\
\text { бюджетной процедуры }\end{array}$ & Не установлен НПА \\
\hline $\begin{array}{l}\text { Внутренняя бюджетная } \\
\text { процедура }\end{array}$ & $\begin{array}{l}\text { ФС ВФА от } 21.11 .2019 \text { № 196н: } \\
\text { процедуры главного } \\
\text { администратора } \\
\text { (администратора) бюджетных } \\
\text { средств, результат выполнения } \\
\text { которых влияет на значения } \\
\text { показателей качества } \\
\text { финансового менеджмента, } \\
\text { определяемые в соответствии } \\
\text { с порядком проведения } \\
\text { мониторинга качества } \\
\text { финансового менеджмента, } \\
\text { предусмотренным п. } 6 \text { ст. 160.2-1 } \\
\text { БК РФ, в том числе процедуры по } \\
\text { составлению и представлению } \\
\text { сведений, необходимых для } \\
\text { составления проекта бюджета, а } \\
\text { также по исполнению бюджета, } \\
\text { ведению бюджетного учета } \\
\text { и составлению бюджетной } \\
\text { отчетности }\end{array}$ & $\begin{array}{l}\text { Не установлена НПА до } \\
30 \text { апреля } 2020 \text { г. - п. } 2 \\
\text { Методических рекомендаций } \\
\text { № 356: внутренние процедуры } \\
\text { составления и исполнения } \\
\text { бюджета, ведения бюджетного } \\
\text { учета и составления бюджетной } \\
\text { отчетности }\end{array}$ \\
\hline Бюджетные риски & $\begin{array}{l}\text { ФС ВФА от 21.11.2019 № 196н: } \\
\text { оценка бюджетного риска - } \\
\text { осуществляемое субъектом } \\
\text { внутреннего финансового } \\
\text { аудита и субъектами бюджетных } \\
\text { процедур выявление } \\
\text { (обнаружение) бюджетного }\end{array}$ & $\begin{array}{l}\text { Не установлены НПА, до } \\
30 \text { апреля } 2020 \text { г. - п. } 3 \\
\text { Методических рекомендаций } \\
\text { № 356: управление событиями, } \\
\text { негативно влияющими на } \\
\text { выполнение внутренних } \\
\text { бюджетных процедур }\end{array}$ \\
\hline
\end{tabular}




\begin{tabular}{|c|c|c|}
\hline Наименование & ВФА & ВФК \\
\hline & $\begin{array}{l}\text { риска, а также определение } \\
\text { значимости (уровня) бюджетного } \\
\text { риска с применением критериев } \\
\text { вероятности и степени влияния в } \\
\text { целях формирования и ведения } \\
\text { реестра бюджетных рисков. } \\
\text { Риск искажения бюджетной } \\
\text { отчетности - бюджетный риск, } \\
\text { выражающийся в возможности } \\
\text { допущения факта искажения } \\
\text { бюджетной отчетности и (или) } \\
\text { данных бюджетного учета, } \\
\text { приводящих к искажению } \\
\text { бюджетной отчетности }\end{array}$ & \\
\hline Методы & $\begin{array}{l}\text { ФС ВФА от 31.11.2019 № 196н: } \\
\text { прием, применяемый при } \\
\text { проведении аудиторского } \\
\text { мероприятия членами } \\
\text { аудиторской группы или } \\
\text { уполномоченным должностным } \\
\text { лицом, в зависимости от целей и } \\
\text { задач аудиторского мероприятия, } \\
\text { результатов оценки бюджетных } \\
\text { рисков, степени обеспеченности } \\
\text { ресурсами (временнымии, } \\
\text { трудовыми, материальными, } \\
\text { финансовыми и иными } \\
\text { ресурсами, которые способны } \\
\text { оказать влияние на качество } \\
\text { проведения аудиторского } \\
\text { мероприятия), и др. } \\
\text { к методам внутреннего } \\
\text { финансового аудита отнесены } \\
\text { аналитические процедуры, } \\
\text { инспектирование, пересчет, } \\
\text { запрос, подтверждение, } \\
\text { наблюдение, мониторинг } \\
\text { процедур внутреннего } \\
\text { финансового контроля }\end{array}$ & $\begin{array}{l}\text { Не установлены НПА, до } \\
30 \text { апреля } 2020 \text { г. - п. } 10 \\
\text { Методических рекомендаций } \\
\text { № 356: самоконтроль, контроль } \\
\text { по уровню подчиненности, } \\
\text { смежный контроль и контроль } \\
\text { по уровню подведомственности }\end{array}$ \\
\hline $\begin{array}{l}\text { Порядок ведения } \\
\text { (рекомендации) карт внутреннего } \\
\text { финансового контроля }\end{array}$ & - & $\begin{array}{l}\text { Не установлен НПА, до } 30 \text { апреля } \\
2020 \text { г. - разд. II Методических } \\
\text { рекомендаций № } 356\end{array}$ \\
\hline
\end{tabular}

\section{Заключение}

По результатам анализа нормативных правовых актов (в том числе утративших силу), регламентирующих осуществление ВФК, ВФА, а также мониторинга качества финансового менеджмента, важно отметить следующее.

В период 2019-2020 гг. много сделано для упрощения процедур ВФК/ВФА, использования нормативных правовых актов при правоприме- нении. Например, отменены Методические рекомендации № 356, 822, их нормы вошли в той или иной степени в ФС ВФА. При этом остаются вопросы при правоприменении. Так, в настоящее время вследствие того, что осуществление ВФК предусмотрено ст. 160.2-1 БК РФ, а цель ведения, требования к его организации и осуществлению (форма, методы осуществления, процедура) не приведены на подзаконном уровне, у субъектов ВФК могут возникать сложности 
в установлении внутреннего порядка осуществления ВФК.

1. В целях упрощения организации ВФК администраторам бюджетных средств можно предложить следующее :

- название ст. 160.2-1 БК РФ изложить в следующей редакции: «Статья 160.2-1. Бюджетные полномочия отдельных участников бюджетного процесса по организации и осуществлению внутреннего финансового аудита, внутреннего финансового контроля»;

- дополнить указанную статью пунктом следующего содержания: «Внутренний финансовый контроль организуется главным администратором бюджетных средств самостоятельно в целях соблюдения внутренних стандартов и процедур составления и исполнения бюджета бюджетов РФ, подготовки и организации мер по повышению экономности и результативности использования бюджетных средств, соблюдения установленных внутренних стандартов и процедур составления и исполнения бюджета по доходам, расходам, источникам финансирования дефицита бюджета, составления бюджетной отчетности и ведения бюджетного учета с учетом положений настоящего Кодекса»;

- сферу действия ст. 19 Федерального закона от 06.12.2011 № 402-Ф3 предлагается ограничить коммерческими организациями, учитывая, что ВФК, осуществляемый администраторами бюджетных средств, включает в себя внутренний контроль совершаемых фактов хозяйственной жизни. При этом в ст. 19 данного Закона пункт «Порядок организации и осуществления организациями бюджетной сферы внутреннего контроля совершаемых фактов хозяйственной жизни устанавливается с учетом положений бюджетного законодательства Российской Федерации о внутреннем финансовом контроле» вводит в заблуждение правоприменителя. В этой связи при правоприменении возникает высокий риск издания локальных правовых актов с одноименным объектом регулирования в целях реализации норм законодательства РФ.
2. Структура системы правового регулирования ВФК, ВФА представляется следующей:

На законодательном уровне - БК РФ.

На подзаконном уровне - федеральные стандарты, содержащие основные определения, принципы, методы, требования к процедуре ВФА для разработки локальных нормативных актов в целях установления ВФК/ВФА.

Указанные мероприятия будут направлены на избежание противоречий и дублирования положений нормативных правовых актов. Отметим, что на подзаконном уровне для более ясного и четкого понимания адресатами норм (администраторами средств бюджета) определяемой методологии структура правового регулирования должна быть ясно изложена. Наличие методических рекомендаций, не являющихся обязательными, усложняет понимание норм при правоприменении.

3. Основные понятия, термины, определения, принципы, используемые в ВФА (ВФК), бюджетном мониторинге качества финансового менеджмента, целесообразно установить один раз в одном документе, учитывая, что значение их для проведения мероприятий по финансовому контролю и аудиту единое. Например, понятия «бюджетные процедуры», «бюджетные риски», а также принципы законности, объективности, системности и пр.

4. Необходимо обеспечить взаимодействие ГФК с системами ВФК и ВФА. Например, по результатам ГФК составляется акт проверки, который направляется проверяемому администратору бюджетных средств. При этом копию акта проверки представляется верным направлять главному администратору бюджетных средств для формирования перечня бюджетных рисков и доведения его в целях предотвращения подобных нарушений в дальнейшем подведомственным организациям. В данном случае речь идет об использовании инструментов риск-ориентированного подхода.

5. Представляется верным принятие мер по повышению качества работы контрольных и аудиторских органов. Например, выявление лучших практик организации и осуществления внутреннего финансового аудита; выявление и устранение системных недостатков при орга- 
низации и осуществлении внутреннего финансового аудита; обеспечение функциональной независимости внутреннего финансового ау- дита. В результате повысится уровень доверия к результатам и выводам, сделанным при проведении ВФК, ВФА.

\section{БИБЛИОГРАФИЯ}

1. Артюхин P. Е. Составление, внешняя проверка, рассмотрение и утверждение бюджетной отчетности: научно-практический комментарий раздела VIII.1 Бюджетного кодекса Российской Федерации // Реформы и право. - 2013. - № 1. - С. 25-34.

2. Голубев А. В. Правовой статус субъектов финансово-бюджетного контроля. - М. : Норма, 2011. - 176 с.

3. Государственный финансовый контроль: современное правовое регулирование / под общ. ред. А. А. Ялбулганова. - Вып. 11. - М. : Библиотечка «Российской газеты», 2014. - 176 с.

4. Козырин А. Н. Правовые основы государственного и муниципального финансового контроля в Российской Федерации // Реформы и право. - 2014. - № 1. - С. 67-75.

5. Контроль в финансово-бюджетной сфере : научно-практическое пособие / И. И. Кучеров, Н. А. Поветкина, Н. Е. Абрамова [и др.] ; отв. ред. И. И. Кучеров, Н. А. Поветкина. - М. : ИЗиСП, Контракт, 2016. -320 c.

6. Право и финансовый контроль : монография / отв. ред. Е. И. Иванова, Н. М. Казанцев. - М. : Эксмо, 2009. - 332 c.

7. Правовое регулирование финансового контроля в Российской Федерации: проблемы и перспективы : монография / отв. ред. Е. Ю. Грачева. - М. : Норма, Инфра-М, 2013. - 384 с.

8. Прокофьев С. Е. Новации в сфере государственного финансового контроля, осуществляемого Казначейством России // Финансы и кредит. - 2015. - № 10 (634). - С. 2-11.

Материал поступил в редакцию 17 мая 2020 г.

\section{REFERENCES (TRANSLITERATION)}

1. Artyuhin R. E. Sostavlenie, vneshnyaya proverka, rassmotrenie i utverzhdenie byudzhetnoj otchetnosti: nauchno-prakticheskij kommentarij razdela VIII.1. Byudzhetnogo kodeksa Rossijskoj Federacii // Reformy i pravo. - 2013. - № 1. - S. 25-34.

2. Golubev A. V. Pravovoj status sub"ektov finansovo-byudzhetnogo kontrolya. - M. : Norma, 2011. - $176 \mathrm{~s}$.

3. Gosudarstvennyj finansovyj kontrol': sovremennoe pravovoe regulirovanie / pod obshch. red. A. A. Yalbulganova. - Vyp. 11. - M. : Bibliotechka «Rossijskoj gazety», 2014. - $176 \mathrm{~s}$.

4. Kozyrin A. N. Pravovye osnovy gosudarstvennogo i municipal'nogo finansovogo kontrolya $v$ Rossijskoj Federacii // Reformy i pravo. - 2014. - № 1. - S. 67-75.

5. Kontrol' v finansovo-byudzhetnoj sfere : nauchno-prakticheskoe posobie / I. I. Kucherov, N. A. Povetkina, N. E. Abramova [i dr.] ; otv. red. I. I. Kucherov, N. A. Povetkina. - M. : IZiSP, Kontrakt, 2016. - 320 s.

6. Pravo i finansovyj kontrol' : monografiya / otv. red. E. I. Ivanova, N. M. Kazancev. - M. : Eksmo, 2009. $332 \mathrm{~s}$.

7. Pravovoe regulirovanie finansovogo kontrolya v Rossijskoj Federacii: problemy i perspektivy : monografiya / otv. red. E. Yu. Gracheva. - M. : Norma, Infra-M, 2013. - 384 s.

8. Prokof'ev S. E. Novacii v sfere gosudarstvennogo finansovogo kontrolya, osushchestvlyaemogo Kaznachejstvom Rossii // Finansy i kredit. - 2015. - № 11 (634). - S. 2-11. 